\title{
Outmaneuvering the Absolute: Hegel, Skepticism, and Love
}

In this essay, I want to accomplish two tasks. On the one hand, I want to explore the role of skepticism in Hegel's system. I will show, as such, how skeptical positions are always pros hen related to the Absolute as the condition for the possibility of any dialectical movement. As such, no form of skepticism stands as an intelligible position in and of itself but as a pointer to the Absolute position outlined in several of his works. On the other hand, I will argue that Hegel has missed an important form of skepticism, which I will call »faithskepticism." This skepticism is not philosophically centered but theologically centered. As such, it offers a counter-Logos that does not unfold into the totality of the Absolute but to the anticipation of new creation in love. I will argue that Hegel, however, not only neglects this form of skepticism, but that also it cannot be sublated into his systematic totality.

I begin with the scope and trajectory of Hegel's Phenomenology of Spirit.

\section{Sense-Certainty and the Absolute}

The Phenomenology of Spirit traces the history and development of consciousness. It observes consciousness mature, by means of dialectical logic, from its inception and most naive standpoints to an Absolute Standpoint - a triumvirate of art, religion, and philosophy - wherein consciousness comes to know itself as itself. In effect, the Phenomenology of Spirit is a pre-science, an invitation to the true science found in the Phenomenology's Absolute standpoint and Hegel's encyclopedic account of such.

Hegel's phenomenology begins in what he calls snatural consciousness. Natural consciousness is consciousness in-itself. It is the natural unreflective state of consciousness before it is bothered by reflective or philosophical consciousness. ${ }^{1}$ In a quite elucidating account of this Hegel writes,

\footnotetext{
1 "In the course of its development, consciousness loses not only what it held to be true from a theoretical point of view, but also its own view of life and of being, its intuition of the world [...] What is most striking for the consciousness engaged in
} 
"Consciousness simultaneously distinguishes itself from something, and at the same time relates itself to it [...] and the determinate aspect of this relating or of the being of something for a consciousness, is knowing. But we distinguish this being-for-another from being-in-itself; whatever is related to knowledge or knowing is also distinguished from it, and posited as existing outside of this relationship; this being-in-itself is called truth. $\ll^{2}$

Natural consciousness, then, is the consciousness of a subject that is over and against an object. This object differs from the consciousness and consciousness differs from its object. The object is, in this instance, the truth of consciousness, the in-itself by which consciousness relates itself to the object in certainty.

Natural consciousness itself, in its most unreflective state, is depicted in the beginning pages of the first chapter of the Phenomenology of Spirit as sense-certainty. Describing this form of consciousness Hegel writes,

"The knowledge of knowing which is at the start or is immediately our object cannot be anything else but immediate knowledge itself, a knowledge of the immediate or what simply is. Our approach to the object must also be immediate or receptive; we must alter nothing in the object as it presents itself. In apprehending it we must refrain from comprehending it. ${ }^{3}$

In other words, we must take ourselves in a purely receptive manner, given over to the givenness of the object in its purity.

To a subject caught within this stage, the deepest truth of an object is its sensuousness, its sense-certainty and re-presentation. "In this belief, thinking goes straight to the ob-jects; it reproduces the content of sense-experience and intuition out of itself, as a content of thought, and is satisfied with this as the truth. ${ }^{4}$ For sense-certainty, the object of consciousness is most properly an unmediated and pure ")this`, or the single item. $«^{5}$ But the object is also the certainty of the

experience is indeed the negative character of its result: it initially posited a truth which had Absolute value for it, but in the course of its journey that truth is lost." J. Hyppolite, Genesis and Structure of Hegel's Phenomenology of Spirit, transl. J. Heckman, Evanston,1974, 13.

2 G.W.F. Hegel, Phenomenology of Spirit, transl. A.V. Miller, New York 1977, 53.

3 Ibid., 58.

4 G.W.F. Hegel, The Encyclopaedic Logic: Part 1 of the Encyclopaedia of Philosophical Sciences with Zusätze, transl. T.F. Geraets/W.A. Suchting/H.S. Harris, Indianapolis 1991, 65.

5 Hegel, Phenomenology of Spirit, 59. 
relation between the subject-object, for the object »is, regardless of whether it is known or not; and it remains, even if it is not known, whereas there is no knowledge if the object is not there. ${ }^{6}$

The goal of the Phenomenology - which »is as necessarily fixed for knowledge as the serial progression « - is not simply to analyze this, or any other particular state of consciousness. Rather, it is to describe the natural progression of consciousness as it methodically unfolds into the Absolute Standpoint and Science proper. ${ }^{7}$

The goal of the Phenomenology, then, is to bring consciousness to the Absolute Standpoint, which itself is the unity of unity and disunity, the resolution of the opposition of nature and spirit in Spirit. In other words, it is the positively rational position wherein all dialectical and speculative moments are sublated into an infinite whole; it is the dissolution of the subject-object divide that is so explicitly given at the level of sense-certainty. And in this resolution, consciousness, having preserved all dialectical developments, takes itself as its most complete object. The goal of the Phenomenology of Spirit is the Absolute and the Absolute is the way of Science. ${ }^{8}$

While the Phenomenology of Spirit begins, then, from the most naive phase of natural consciousness in sense-certainty, Consciousness at this level is merely a seed of the Absolute Standpoint. And in order to blossom, consciousness must face a series of negations, and speculative encounters which mediate and cleanse consciousness of its half-truths. Thus, Hegel says of his Phenomenology of Spirit that,

"it can be regarded as the path of the natural consciousness which presses forward to true knowledge; or as the way of the Soul which journey's through the series of its own configurations as though they were appointed of it by its own nature, so that it may purify itself for the life of the Spirit, and achieve finally, through a completed experience of itself, the awareness of what it really is in itself. «"

The Phenomenology plots the pathway that all true understanding must first follow.

\footnotetext{
Ibid.

Ibid., 48

8 Ibid.

9 Ibid., 49.
} 


\section{The Nature of Dialectical Logic}

I have first noted that the beginning of consciousness is natural consciousness, the in-itself, and its goal is Absolute consciousness in the Absolute standpoint, the in-and-for-itself of Absolute Science. Furthermore, I noted that a dialectical process brings about this goal. But what exactly is the nature of this process? To answer this we shall turn to Hegel's The Encyclopedia Logic and define the essence of thinking in terms of dialectical logic. ${ }^{10}$

"With regard to its form, " says Hegel, "the logical has three sides: $(\alpha)$ the side of abstraction or of the understanding, $(\beta)$ the dialectical or negatively rational side, $(\gamma)$ the speculative or positively rational one. ${ }^{11}$ The first moment of dialectic is the moment of understanding. The understanding, for Hegel, can itself be understood in fashion similar to Kant: understanding is the application of finite categories to experience; or in more precise Hegelian terms, the application of finite categories to objects within a stage of consciousness. The understanding, then, plays an extremely important and foundational role in Hegel's logic insofar as without it, "there is no fixity or determinacy in the domains either of theory or practice. $^{12}$

In both theory and practice, then, understanding is marked by the law of identity, "by apprehending objects in their determinate distinctions. ${ }^{13}$ To determine the theoretical "whatness" of an object is to determine its identity against a multitude of separate objects, each of which has its own identity. The understanding is, thus, the beginning of all scientific cognition. ${ }^{14}$ For example, insofar as similar identities can be similarly understood, to determine something's identity is to open up the world of universals, ${ }^{15}$ furthermore, insofar as similar identities are similarly understood, universal identities can be related to one another to build scientific systems and systems can be further related to build more comprehensive systems, etc. (perhaps, in critique, not unlike the Phenomenology of Spirit itself).

Aside from its specific use, no matter what the dialectical stage, the understanding serves as a necessary foundation from which the

\footnotetext{
${ }^{10}$ Hegel, The Encyclopaedic Logic: Part 1 of the Encyclopaedia of Philosophical Sciences with Zusätze, 125

11 Ibid.

12 Ibid., 126.

13 Ibid.

14 Ibid., 126.

15 "[I]n mathematics, magnitude is the one determination with respect to which a progression happens, all others being left out. In the same way we compare figures with one another in geometry, bringing out what is identical in them. "Ibid.
} 
other moments of logic dynamically flow. However, understanding, until reaching the Absolute, faces a continual dilemma: because it is finite and the Absolute infinite, until reaching the Absolute the understanding must be continually usurped and sublated.

What, however, would it mean for consciousness, in the understanding, to be either finite or infinite - for that matter? Finitude for Hegel is "whatever comes to an end, what is, but ceases to be where it connects with its other, and is thus restricted by it. ${ }^{16}$ Finitude, in other words, is the restriction of a concept by another concept of equal truth-value. On the other hand, infinitude - in its good sense - for Hegel means the Absolute sublation of all difference, so that there is nothing outside of that which is defined. Essentially, infinity signifies that is not bound by anything but itself, that is, there is no subject-object divide by which a contradictory viewpoint and limit could be proposed. ${ }^{17}$ As H.S. Harris comments,

"What is distinctive about Hegel's usage of [infinity] is that, in order to be without any externally bounding "relations, " that which is "Absolute " must logically contain (or comprehend) all finite relations and necessities. It cannot simply be "other" than they are - for that itself would be a "relation« to them. ${ }^{18}$

Infinity is the Absolute.

Because the understanding is finite, it necessarily overturns itself into its opposite concept. This overturning, then, is the second moment of dialectical movement. As expressed by Hegel, this negative moment "is the immanent transcending, in which the one-sidedness and restrictedness of the determinations of the understanding displays itself as what it is, that is, as their negation. ${ }^{19}$ The dialectical moment is, upon genuine consideration, the negation of what seems to be positively certain in the understanding into its opposite truth: the development of a finite concept into its opposite, contradictory concept.

Take, for example, the master-slave dialectic in the Phenomenology of Spirit. It is the Master who seems to have gained humanity because it is he who was willing to risk life in order to gain the other's desire,

16 Ibid., 67

17 Ibid., 150 .

${ }^{18}$ Ibid., 324 footnote 4. Moreover, in the editor's preface, the author expresses that it is H.S. Harris who wrote most of the philosophical and historical footnotes. Ibid., ix. Bad infinity for Hegel is the infinity with no determinacy, infinity which continually passes over into concept after concept. Ibid., 323.

19 Ibid., 128. 
and it is the slave who, in fearing death - or loving life - agrees to serve the master, depriving himself of genuine humanness. But, in reality, it is the Master, who, in delegating his work to the slave and spending his life in either war or leisure, becomes a slave to his own enjoyment, while the slave is transformed into the truly human inasmuch as his being is mediated through labor and thought.

Once again, this movement is exemplified in Kant's antinomies, "which in no way involves a seesawing between opposite grounds as a merely subjective activity, but rather exhibits how each abstract determination of the understanding, taken simply in its own terms, overturns immediately into its opposite. $\ll^{20}$ For Kant - as Hegel understands him - the understanding proposes two contradictory concepts which are both seemingly necessary, neither of which the understanding cannot overturn. The understanding, thus, finds itself at an impasse. Though thoroughly dissatisfied with its position, it is unable to move beyond these finite understandings.

So the original determinations of understanding, upon dialectical reflection, pass over into a second and contradictory moment. But, this moment is still only a grasp of the finite understanding - albeit an understanding diametrically opposed to its first. This movement, then, is overturned in a third, speculative movement: the positively rational.

The positively rational moment is the moment of speculation. It is the movement of reason, the movement beyond the merely empirical, finite and abstract categories into the realm of concrete unifying thought. ${ }^{21}$ The positively rational moment is, thus, the moment of transcendence whereby the thinker is pushed beyond the abstract identities of the understanding in both of its contradictory phases, sublating and containing them as ideal moments within the new speculative and rational concept. ${ }^{22}$

It is, then, the movement into a new position, a quantum jump into a new understanding, a determination that will ground further finite determinations. ${ }^{23}$ Until Absolute Science is reached, the positively rational moment continually grounds a new dialectic, whereby

\footnotetext{
${ }^{20}$ Ibid., 130

21 Ibid., 131.

22 Ibid., 133.

23 "The mere logic of the understanding is contained in the speculative Logic and can easily be made out of the latter; nothing more is needed for this than the omission of the dialectical and the rational; in this way it becomes what is usually called logic, a descriptive collection of determinations of thought put together in various ways, which in their finitude count for something infinite." Ibid.
} 
a further negation and a further rational moment will necessarily appear.

\section{The Role of Skepticism in Hegel's System}

Having defined the scope, goal, and role of the three moments in the dialectical process, I will now turn and consider the role of doubt within this same process, trying to understand how it enables the dialectical process to move forward. For Hegel,»[t]he skepticism that is directed against the whole range of phenomenal consciousness [...] renders the Spirit for the first time competent to examine what truth is. $\aleph^{24}$ But what is this doubt that will accommodate the work of the Spirit and its dialectical unfolding? To determine this concept, I plan to examine three forms of doubt: modern skepticism, high ancient skepticism, and Socratic skepticism. The two prior notions Hegel rejects, albeit to varying degrees, while he finds in the latter an insight of key importance for his own system.

To begin, we shall define the scope and inadequacy of modern skepticism. Capturing Hegel's critique of this mode of skepticism, Hyppolite states "Modern skepticism attacks only metaphysics and leaves the unshakable certainties of common sense untouched. ${ }^{25}$ That is, modern skepticism is unwarranted, built not upon the universal doubt it claims to uphold, but upon a bias of common sense. ${ }^{26}$ Common sense, then, is a mode of thought that, by habituating certain proposals and categories, envelopes itself in their immediacy, calling these categories experience - which is the perceived foundation of common sense - while protecting them from the wild auspices of speculative thought.

Thus, For Hegel,

"Knowing, believing, thinking, intuiting are the categories that occur at this [modern commonsensical] standpoint; and since these categories are presupposed as already familiar, [that is, commonsensical], they are often employed in accordance with merely psychological notions and distinctions. What their nature and concept is, is not investigated - though that is what everything depends on. $\|^{27}$

${ }^{24}$ Hegel, Phenomenology of Spirit, 50

${ }^{25}$ Hyppolite, Genesis and Structure of Hegel's Phenomenology of Spirit, 13.

${ }^{26}$ Hegel, The Encyclopaedic Logic: Part 1 of the Encyclopaedia of Philosophical

Sciences with Zusätze, 112.

${ }^{27}$ Ibid., 110. 
The problem with modern skepticism is epistemological; that is, it is based upon an understanding of thinking as looking, as immediate confrontation with an object. Modern skepticism cannot distinguish between reality and appearance; and because it perceives true knowing to be immediate, it seeks to reduce cognition to an instrument and truth to intuition, thereby committing all metaphysics, or that which is not immediately apparent - what is mediated - to the flames. ${ }^{28}$ What is true is either the object as immediately present - much like sense certainty - or the object as something inwardly universal, an intuition. But, to think about an object is to apply to it an instrument or a medium. And if thought is an instrument, »it is obvious that the use of an instrument on a thing certainly does not let it be what it is for itself, but rather sets out to reshape and alter it. $\ll^{29} \mathrm{Or}$, if cognition is a medium, "then again we do not receive the truth as it is in itself, but only as it exists through and in this medium. $\otimes^{30}$

Contesting this treatment of cognition and the bias of modern skepticism, Hegel holds that we need not superimpose an artificial, commonsensical, empirical criterion upon the truth of consciousness - as if "there is a difference between ourselves and our cognition ${ }^{31}$ - for such a criterion is merely a matter of presupposition. Indeed, when trying to superimpose such a criterion, "philosophy must in any case rest entirely content with the assertion and demonstration that its propositions are also facts of consciousness and hence that they are in agreement with experience. $\aleph^{32}$ But, for Hegel, this position requires an astounding leap of faith. It mistrusts cognition while completely and naively trusting experience. Why not, rather, "mistrust this very mistrust « of cognition? ${ }^{33}$ And rather than depending upon an external empirical criterion, recognize that "[c]onsciousness provides its own criterion from within itself, so that the investigation becomes a comparison of consciousness with itself". Consciousness, rather than seeking a truth beyond itself, is, or at least becomes, its own truth. ${ }^{34}$

\footnotetext{
${ }^{28}$ D. Hume, An Enquiry Concerning Human Understanding and a Letter from a Gentleman to His Friend in Edinburgh, Indianapolis, Sect XII part III, 1977, 132.

${ }^{29}$ Hegel, Phenomenology of Spirit, 47.

${ }^{30}$ Ibid.

31 Ibid.

${ }^{32}$ Hegel, The Encyclopaedic Logic: Part 1 of the Encyclopaedia of Philosophical Sciences with Zusätze, 113.

${ }^{33}$ Hegel, Phenomenology of Spirit, 47.

34 Ibid., 53.
} 
So with regard to the foundations of modern skepticism and its love of common sense, Hegel facetiously writes,

»The last thing philosophy would want to do is contradict these propositions of immediate knowing; on the contrary, it can congratulate itself upon the fact of its own old propositions, which even expressing its entire universal content, have somehow become also the general prejudices of the times - though in a quite un-philosophical way to be sure. $\aleph^{35}$

Common sense, then, is a poor foundation upon which to build a skeptical point of view, or to initiate the constructive doubt necessary for the unfolding of Spirit in Science; indeed, rather than impelling the dialectical process and the unfolding of Absolute Science or Spirit, modern skepticism serves only as an impediment, an insignificant obstacle to be overcome - or at best, a moment of which Spirit will cleanse itself. Thus, it is easy enough to see why Hegel rejects modern skepticism: modern skepticism is nothing but positivism, ${ }^{36}$ a naive metaphysical position that, refusing to see its inherently metaphysical stance, tries to nullify metaphysics.

Having rejected modern skepticism, I want to revert back to Hyppolite's comment on modern skepticism. Hyppolite stated that $"[$ m] odern skepticism attacks only metaphysics and leaves the unshakable certainties of common sense untouched". However, Hyppolite goes on to say, »but it is precisely these certainties that ancient skepticism meant to shake. "There is something substantially different, according to Hyppolite, between modern and ancient skepticism. Something is more attractive in the latter. What, then, attracts Hegel to ancient skepticism? To answer this, we must define and explain the importance of two types of ancient skepticism: high skepticism and Socratic skepticism. I will treat these in order.

High ancient skepticism, as Hegel calls it, is essentially a moral skepticism. It is a skepticism that suspends all judgment of reality to reach a state of quietude, "an untroubled and tranquil condition of the soul. ${ }^{37}$ As expressed by Sextus Empiricus - one of the greatest of the high ancient skeptic - the ancient metaphysicians (or »dogmatists" as Empiricus calls them) sought quietude through positive knowledge of the cosmos, by knowing truth from falsity, reality from

${ }^{35}$ Hegel, The Encyclopaedic Logic: Part 1 of the Encyclopaedia of Philosophical Sciences with Zusätze, 112.

${ }^{36}$ Hyppolite, Genesis and Structure of Hegel's Phenomenology of Spirit, 13.

${ }^{37}$ Sextus Empiricus, Outlines of Pyrrhonism, Book 1, 4, 10. 
appearance. ${ }^{38}$ Due, however, to the failure of these metaphysicians to agree upon reality, they could never reach quietude. Thus, the skeptics, for the sake of quietude, rejected the possibility of knowing reality altogether.

To reach a state of quietude the skeptic employs ten techniques. These techniques allow him to counter any positive truth claim asserted by a dogmatist and suspend their judgment. Rather than explaining these ten techniques, it should suffice to articulate the principle underlying all of them. As Sextus Empiricus states,»[t]he main basic principle of the skeptic system is that of opposing to every proposition an equal proposition; for we believe that as a consequence of this we end by ceasing to dogmatize. ${ }^{39}$ The skeptic, then, seeks to counter any positive dogmatic determinations with coequal determinations of a contradictory nature, enabling the skeptic to rest securely in their suspension of judgment. In other words, the high ancient skeptic issues an antinomy, a dialectical negation.

Why, however, is high skepticism for Hegel superior to modern skepticism? According to Hegel, high skepticism "is complete despair about everything that the understanding holds to be firm, and the disposition that results is imperturbability and inward repose. $\aleph^{40}$ The goodness and usefulness of high skepticism lies in its Absolute doubt of all finitude. That is, the high skeptic seeks to annul all positive knowledge of the understanding inasmuch as it is not Absolutely certain, insofar as it is not contained in an infinite determination, insofar as it is not an Absolute Science. ${ }^{41}$ However, high skepticism fails, according to Hegel, to grasp the nature of the Absolute, or more specifically, that there is an Absolute. So Hegel states,

"This is just the skepticism which only ever sees pure nothingness in its result and abstracts from the fact that this nothingness is specifically the nothingness of that from which it results [...] The skepticism that ends up with the bare abstraction of nothingness or emptiness cannot get any further from there, but must wait to see whether something new comes along and what it is, in order to throw it too into the same empty abyss. ${ }^{42}$

\footnotetext{
${ }^{38}$ Ibid., Book 1, 6,12.

39 Ibid.

${ }^{40}$ Hegel, The Encyclopaedic Logic: Part 1 of the Encyclopaedia of Philosophical Sciences with Zusätze, 131.

${ }^{41}$ " Equipollence $<$ we use of equality in respect of probability and improbability, to indicate that no one of the conflicting judgments takes precedence of any other as being more probable.« Sextus Empiricus, Outlines of Pyrrhonism, Book 1, 4,10.

${ }^{42}$ Hegel, Phenomenology of Spirit, 51.
} 
Because of this, high skepticism cannot move beyond skepticism, beyond the dialectical moment into the positively rational speculation. The skeptic only seeks to negate all positive determinations. ${ }^{43}$

Indeed, Hegel demonstrates in the Phenomenology of Spirit that such empty abstractions lead not to quietude, but to "unhappy consciousness, " a state of severe $u n$-quietude that, while claiming to deny the Absolute, unconsciously continues to seek the Absolute. ${ }^{44}$ Thus, Hegel, while recognizing a positive element in this skeptical position, must necessarily reject it since its truth is the total suspension of truth. This leaves room, then, only for Socratic Skepticism.

In the Apology, Socrates notes that his accusers call him »a wise man, a student of all things in the sky and below the earth, who makes the worse argument the stronger. ${ }^{45}$ The majority of the Athenian population thus knows him, more or less, as a skeptic (or more precisely a sophist - though Socrates certainly contends otherwise). But in what sense is Socrates actually a skeptic?

Socrates seeks universal concepts, more specifically universal virtues; and though Socrates himself cannot provide universal definitions of the virtues, neither is he content to receive particular answers from his colleagues. For example, in the Republic, while Socrates converses with his friends concerning the nature of justice, the sophist Thrasymachus bursts into the dialogue haughtily proclaiming, "what if I show you a different answer than all of these - and a better one? ${ }^{46}$ Thrasymachus goes on to define justice as merely "the advantage of the stronger. ${ }^{47}$ But, of course, Socrates is not satisfied with this answer, for it may or may not capture an aspect of justice, but it is certainly not justice in-itself. Socrates thus brings Thrasymachus through a series of arguments wherein Thrasymachus must concede his position.

Due to this encounter and many others like it, Socrates is called a skeptic because, though he is a master of refuting others' arguments, he cannot assert one of his own. Socrates desires universal definitions and will settle for nothing less, even though he himself cannot provide the answers. Thus, if Socrates is a skeptic, then he is a skeptic not because he is skeptical of reason, but because he accepts neither common-sense propositions nor Sophistic rhetorical judgments as

${ }^{43}$ Ibid.

${ }^{44}$ Hyppolite, Genesis and Structure of Hegel's Phenomenology of Spirit, 190.

45 Plato, Apology, 18c.

${ }^{46}$ Plato, Republic, $337 \mathrm{~d}$.

${ }^{47}$ Ibid., 338 b. 
true $;^{48}$ he is satisfied by nothing less than a universal definition of a virtue.

Hyppolite thus notes that, because Socratic skepticism sought to shake the bonds of common sense, "as with Plato, skepticism served as something of an introduction to metaphysics, and every philosophy at the time included a moment of skepticism by which it purified naive consciousness. " ${ }^{49}$ Socratic skepticism, then, just as the skepticism of Sextus Empiricus, demonstrates a lack of willingness to accept the finitude of common-sense understanding. However, Socratic skepticism supersedes high skepticism with its positive desire to push through the empty abstractions of the merely skeptical stage - a desire that does not search for quietude in the mere negation of every positive proposition, but only in the Absolute Science. Socratic skepticism searches for quietude only in infinity.

\section{Hegel's Sublation of Skepticism}

So far, I have in this essay attempted to determine the role of skepticism in Hegel's metaphysical system. With regard to this aim, it can be isolated as a recurrent manifestation of Socratic skepticism: a notional realization of the Absolute that leads to a doubt of all finitude. Such a notion brings to mind, then, the following words of Hegel: »[t]he dialectical road can therefore be regarded as the pathway of doubt, or more precisely the way of despair. $\star^{50}$ That is, the doubt found within skepticism in any form is a necessary and recurrent "attitude" on the part of Spirit as it develops through knowing subjects. An attitude which, as doubt of the certainty of a determination and the death of some world historical position, allows Spirit to make the transition from a position to its negation, or even from the negation to speculation. What, then, in the end can we say about doubt and skepticism in Hegel? Doubt, and its systematization in skepticism, is the condition for the possibility of all dialectical movement within Hegel's system - Skepticism allows Spirit to posit the antinomies by means of which the speculative moment can take hold and lead to the Absolute.

What this understanding of skepticism means is, perhaps, even more important. Hegel sublates all forms of skepticism by showing

\footnotetext{
${ }^{48}$ Hegel, The Encyclopaedic Logic: Part 1 of the Encyclopaedia of Philosophical Sciences with Zusätze, 129.

${ }^{49}$ Hyppolite, Genesis and Structure of Hegel's Phenomenology of Spirit,13.

${ }^{50}$ Hegel, Phenomenology of Spirit, 49.
} 
that, although important, they are entirely privative positions, dependent in their ultimate meaning upon their positioning materially and formal within the Absolute. As such, it seems that Hegel holds that no skeptical position could ever stand on its own two feet apart from something like the Absolute. Indeed, if we choose to move down Hegel's path, he seems to show that, in some form, one cannot get around the fact that persons assume something like a Logos in the form of something like the Absolute, even in their denial of any form of Logos. Such a denial in itself becomes a Logos, a centering point from which to draw out (the denial of) all intelligibilities in a skeptical manner.

Skepticism, then, is a purely privative ideal, bound always and in itself to the unfolding of a positive viewpoint, a turn away from which is an inauthentic denial of Spirit in its concrete and manifest unfolding. My point, however, in elucidating Hegel's appropriation and sublation of skepticism stems not from a concern to refute the skeptic in the terms that Hegel has outlined; he seems to have done a good enough job with the forms of skepticism to which he points. Rather, I want to see if Hegel has, indeed, accounted for all forms of skepticism in his reflections on the matter or whether any forms remain untouched.

\section{Moving beyond Hegel through a Counter-Logos}

The main problem with Hegel's accounts of skepticism is that he only draws out various philosophical notions of skepticism. However, a philosophical skepticism thinks only in terms of what I want to call a philosophical Logos: a Logos that takes Being in its intelligible "self-relatedness" (for lack of a better term) as the highest possibility of the Logos. Despite Hegel's philosophical reduction of the Logos, there may be room for an altogether different form of skepticism that grounds its skeptical approach in a critique of the philosophical Logos without ever being bound to it for its positive intelligibility. For lack of a better term, I want to awkwardly but rightly call this skepticism a "faith-skepticism. "I will illuminate this possibility to a degree in the rest of what follows.

The first and most distinctive aspect of this faith-skepticism pertains to the placement of the Logos. For Hegel, his philosophical Logos is contained primarily within the general and necessary structures of Being as related to thought. Hegel thinks through the Logos in a manner similar to both Aristotle and Plato alike, albeit more 
dynamically and concretely. The Logos is found for Hegel in that often overused term the "God of nature, " which he panentheistically reinterprets through the historical events of world Spirit and its unfolding.

Faith-skepticism, on the other hand, finds the Logos primarily in the meaning of a seemingly contingent event, namely, a meaning illuminated in and through the life, death, and resurrection of a singular person at a specific time and in a specific place. The Logos is found in the Divine's association neither with the world nor with is mode of operation, but only with the man on the cross, who, as the parable of God, altogether calls into question Hegel's understanding of world Spirit and its historical unfolding. ${ }^{51}$ To make this same point in another but important manner, according to faith-skepticism, Hegel has mistaken the order of hierarchy within his Absolute. He has placed the highest form of discussing the Absolute within the realm of philosophy, for philosophy talks directly about its content, allowing that content to return to itself conscientiously. ${ }^{52}$

The second aspect of this faith-skepticism that Hegel fails to account for pertains to the character of this self-same Logos. Because Hegel treats the Logos primarily and at its fullest point philosophically, he understands the Logos as, once again, consisting of a totalizing self-relationship wherein thought, in the nascent opening up in Being, begins unfolding itself so as to become conscious of itself in an absolutely (solipsistic) self-relationship for itself. The most important word in the previou s sentence is the object of the preposition "for" because the term signifies the end toward which the Absolute is oriented - as in all good philosophical positions, itself.

The question, however, is whether the philosophical mode of accounting for the Logos and the opening up of consciousness to itself

\footnotetext{
${ }^{51}$ E. Jüngel, God as the Mystery of the World: On the Foundation of the Theology of the Crucified One in the Dispute between Theism and Atheism, Grand Rapids 1983, 302.

${ }_{52}$ As an aside, one must be careful, here, for it might seem that Hegel has already sublated this very idea within his systematic unfolding of the Absolute in his talk of the death of God. For certainly within his Phenomenology, Hegel not only talks about the death of God, but it forms a sort of climax, leading into Spirit's dénouement and Spirit's capacity to truly grasp itself in Spirit. The problem is that, based on his understanding of the hierarchy within the Absolute, Hegel sees this so-called death of God as the beginning of the sublation of his "bad infinity into what will eventually emerge as a "good infinity" that is the totality of the Absolute. It is not wrong, in other words, to refer to the self-identification of God with Christ on the cross and in the resurrection for Hegel; it is simply more correct to speak in purely philosophical terms about the idea, terms that allow thought to fold back on itself, in itself, for itself.
} 
in a differentiated unity is the only conceivable form for the Logos? The Christian tradition seems to offer a differing understanding of the Logos: that the Logos is constituted by love. The Logos of love, however, refers to the character of creation and the reason for its creation. As love itself, the Divine (which now takes a much different form than the Absolute or World Spirit) remains the Divine by relating to those of "us " in the world through persons in the world as completely other than us. It does this, however, not immanently nor for the sake of coming back to itself as differentiated conscious; the Divine relates to us for our sake and as the transcendent Other who is irreducible to this world even in its relationship to that man on the cross who has been extant within this world. ${ }^{53}$ The Other, then, does not exist for the sake of the Divine to come back to itself in differentiated consciousness; rather, the Divine is certainly a self-relation, but is such for the sake of freely relating to us in our Otherness. All self-relatedness in God is found in God's relationship to God's selfexpropriation and all self-expropriation is possible because of God's self-relatedness. (This is the wisdom behind, for instance, Rahner and Jüngel's claims alike that the immanent Trinity is the economic Trinity.)

\section{A Distinct Form of Skepticism?}

With these elucidations in mind, I return to the notion of skepticism, drawing out the implications of the above ideas in relationship to it. For one, we should note the basic hermeneutic insight that the Logos, Being, and our interpretations of being are never completely separate phenomenon; rather, each are found in and relative to the others. Accordingly, the Logos is that which informs the intelligibility that emerges as Being, and knowing is always directed toward Being's intelligibility. Moreover, knowing is always informed by the particular horizon within which the knower finds herself, which in turn informs the Logos of Being that the knower can interpret. The Logos, Being, and knowing form, then, something of a primordial unity of correspondences or correlations from the standpoint of the knower. Two important facets of faith-skepticism can be drawn out of this original correlation.

Knowing, in some important sense, always takes its lead from the contours of Being, which itself is always determined by the Logos organizing its intelligibility. What there is to know is only found

${ }^{53}$ Jüngel, God as the Mystery of the World, 320, 327. 
with the Logos informing Being and the character of this Logos. If the character of this Logos is, as Hegel argues, grounded in some Absolute standpoint wherein the contours of everything about everything are predefined and, ultimately, unfolded in his system, then the possibilities that one can know within Hegel's system are limited to the actualities found in Spirit's return to itself.That is, all possibilities are predetermined by the solipsistic nature of Spirit. This has an important implication: the possibility of knowledge is always already fixed.

That is, knowledge is fixed by the internal limitations of the Spirit's Logos as it returns to itself in the Absolute. While everything can be potentially known in this self-return, nothing can be known outside of this return, for there is nothing outside of this self-return not already (potentially) illuminated in Spirit - and even nothingness is sublated in becoming for Hegel! This is why, for instance, Hegel can sublate each form of skepticism outlined above, showing how all of them are ultimately pointers to Spirit in its Absolute manifestation.

This is also why Kierkegaard, through his pseudonym Constantin Constantius in his Repetition, refers to Hegel's notion of becoming as an imitation of any form of true becoming; the becoming of Spirit is already predefined by its possibilities, the basics of which are found in Spirit's seed-like nature in Being. ${ }^{54}$ This is also why Kierkegaard as the same pseudonym in the same book goes on to state that Hegel's conception of knowing is defined entirely by anamnesis. When there is nothing truly new to know, then one can merely "remember" what has always already been. In this regard Hegel is at one with the classical thinkers that he seeks in many ways to overcome. ${ }^{55}$

On the other hand, no such anamnesis defines knowledge when Being itself is not permanently fixed by a single set of actual possibilities. And this is precisely why an understanding of Being informed by a Logos characterized by love elicits something like a form of faith-skepticism. Love is always dedicated to, and in a relationship with, otherness such that love desires to draw that otherness into a relationship of love in that other's otherness. And when love characterizes the Logos, the Logos is itself constituted not by a selfrelationship but by an other-relationship, which it constantly and in all ways moves into and toward.

In other words, the Logos and the Being flowing from this Logos never stands stagnant, as a set of complete actualities with no further

\footnotetext{
${ }^{54}$ S. Kierkegaard, Fear and Trembling; Repetition, transl. H.V. Hong/E.H. Hong Princeton, 1983, 148-149.

55 Ibid.
} 
room for possibility. The very concept of love is a self-exploding unity to be understood in much the same way that Levinas tries to exegete the idea of the face of the other as related to infinity. ${ }^{56}$ As love, the Logos is always moving into new and other possibilities, opening up in its self-expropriation what was before closed off to view and unable to be known - what was not yet. Love, then, moves constantly into what is not, opening up, and creating new Being - new possibilities - out of nothing, never giving itself over to a totalizing Absolute which can be known through anamnesis but through an ever-present openness to the Divine as it opens up new possibilities through its self-understanding as love.

A number of other important implications can be drawn from these reflections. Were I to continue down this line of thought, I would interpret the relationship between self-knowing and the knowledge of Being more precisely, which is always something of a self-overcoming and expropriation. What is more important for now is to draw out the relationship of these reflections more precisely to the idea of skepticism and Hegel's rejection of it. Again, Hegel rejects the idea of skepticism because he thinks that it can merely stand, both as a material moment within the Absolute and as a negation, as the condition for the possibility of propelling Spirit forward in its completion of self-knowing. When skepticism, thus, takes the form of a position toward the Logos, it can only do so privatively, as already assuming an intelligibility within the Logos that it has somehow achieved in a purely negative move. Any skeptical position, then, is at best privative, helpful for moving Spirit forward but certainly not cognizable as the end of Spirit in the Absolute.

Yet, when the Logos is no longer conceived in terms of a pure self-relation, but rather as a self-expropriation, neither is the Logos any longer conceived of as limited in a strict sense by a set of primordial possibilities already extent with that Logos in its eternal beginning. Or, rather, because Being, defined as it is by a Logos of love, itself is open to new possibility, so too is the knowing that knows Being and its possibilities. The eternal beginning of the Logos is the concreteness of its overflowing possibilities. In this regard, Being as a whole - as an Absolute - can never be grasped, but can only ever be anticipated in a constantly emerging future and extension of the Logos as love into the Otherness that does not yet know love.

${ }^{56}$ E. Lévinas, Totality and Infinity: An Essay on Exteriority, transl. A. Lingis, Pittsburgh 1969, 194-197. 


\section{Conclusion}

With these brief reflections in mind, this paper arrives at two final questions: (1) does this understanding of faith-skepticism really constitute a skepticism and (2) how does this displacement of the Hegel's Logos as self-return with a Logos of love overcome Hegel's sublation of skepticism? With regard to the first question, the answer might vary. This so-called faith skepticism is really a form of skepticism to the degree that any formation of the Absolute constantly overturns itself in the ever outward expansion of the Logos into Otherness. There is, then, no Absolute to be known and, thus, no knowledge in Hegel's understanding of the idea: as the sure and necessary connection of all moments within the Absolute. There is only that knowledge of the concrete, grammatical point that the Logos moves forward in love, which will always force an emendation of one's interpretation of Being. However, there remains within this faith-skepticism something like knowledge. For one, one can paradoxically know the Logos as love. Second, one can know the possibilities that have, indeed, emerged as Being, despite these possibilities not having the final say over what the Logos can draw forth in the future.

One may, in this regard, call this "faith-skepticism" a skepticism, depending on the strength of the idea of skepticism that one demands be upheld by the term. It may, from the standpoint of faithskepticism, be better to say that this interpretation of the Logos is simply faith, no qualifying "skepticism" needed. Indeed, from this position, skepticism might itself be interpreted as a derivative form of faith, trying to achieve the results of faith without faith's understanding of the Logos. That point, however, is perhaps neither here nor there for this particular essay.

What is important, however, is whether this faith-skepticism overcome Hegel's critique of skepticism. In this regard, Hegel's critique of the skeptic is that the skeptic can only hold to the position of skepticism privatively by holding to a self-contradictory knowledge of the Logos as unknowable, therefore positing a negative movement within the unfolding of Spirit as the whole of Spirit in the Absolute. However, the faith-skeptic, which Hegel has not properly conceived, rejects the Absolute as a possibility of the Logos based on the Logos' character as conceived in terms of love. However, by rejecting the Absolute, the faith-skeptic does not deny that she comes to know anything whatsoever: she can know the possibilities of Being as they currently present themselves. It is just that these possibilities are not 
the only possibilities because the Logos is constantly expanding into new possibilities which are not yet known and that will reconstitute Being's totality.

In other words, the faith-skeptic denies the possibility of any form of Absolute knowledge through an Absolute knowledge that the Logos is overflowing in possibilities. This, it seems, directly overcomes Hegel's critique.

USA. 